\title{
Social Experiments on Problems from Tomato Farmers during Covid-19 -Indonesia Case
}

\author{
Syaharuddin Yijo ${ }^{1}$, Asnawati Asnawati ${ }^{1}$, Surya Darma ${ }^{2}$, Gusti Noorlitaria Achmad ${ }^{1}$ \\ M. Alvianto Putra Arizandi ${ }^{3}$, Tetra Hidayati ${ }^{1}$, Dio Caisar Darma ${ }^{3}$ \\ ${ }^{1}$ Mulawarman University, Faculty of Economics and Business, Samarinda, Indonesia \\ ${ }^{2}$ Mulawarman University, Faculty of Agriculture, Samarinda, Indonesia \\ ${ }^{3}$ Sekolah Tinggi Ilmu Ekonomi Samarinda, Department of Management, Samarinda, Indonesia
}

\begin{abstract}
The challenge of Gapoktan tomato still depends on the infrastructure and it is approved by the network built by the government. The focus of the study is to find answers from tomato farmers about water and electricity infrastructure problems during the Covid-19 pandemic. We use social-based qualitative consultations with farmers who are members of Gapoktan tomatoes in Indonesia. Samples from this studio totaled 72 units of informants consisting of 12 questions. The question items are grouped into 2 indicators (social and economic). The conclusion of the study was revealed if answering informants was indeed very varied. At present, there has not been a significant problem with the two indicators discussed in the estimation of water and electricity infrastructure. Therefore, the electricity and water supply in the agricultural area is minimal; bias can lead to new problems such as social conflicts and income from farmers decreased due to Covid-19. This survey can be a reference and consideration for various parties related to the management of tomato cultivation in Indonesia.
\end{abstract}

Keywords - tomato cultivation, electricity and water supply, socio-economics, primary survey, Indonesia.

DOI: $10.18421 /$ SAR41-02

https://doi.org/10.18421/SAR41-02

Corresponding author: Surya Darma,

Mulawarman University, Faculty of Agriculture.

Samarinda, Indonesia

Email: surya_darma@faperta.unmul.ac.id

Received: 14 February 2021.

Revised: 06 March 2021.

Accepted: 16 March 2021.

Published: 22 March 2021.

(c))BY-NC-ND (C) 2021 Syaharuddin Yijo et al; published by UIKTEN. This work is licensed under the Creative Commons Attribution-NonCommercial-NoDerivs 3.0 License.

The article is published with Open Access at www.sarjournal.com

\section{Introduction}

Agriculture became one of the sectors that dominated the structure of Indonesia's Gross Domestic Product (GDP) according to business in 2019. The agricultural sector structure was $13.45 \%$ or the second highest after the industrial sector was $19.62 \%$ in the $3^{\text {rd }}$ quarter. The growth of the agricultural sector was 3,08 from the previous year (year-on-year). However, the growth experienced a decline in the same period of $3.66 \%$.

There is a phenomenon of decreased food crop production due to the dry season. As a result, food crops in the 3rd quarter of 2019 grew negatively by $4.81 \%$. This figure decreased from the second quarter (2019) which was $5.13 \%$ and the third quarter of 2018 was $3.08 \%$. Meanwhile, horticultural crops grew $5.07 \%$ and plantation crops $4.98 \%$ [1].

The agricultural sector has so far been able to absorb the second-highest workforce after the industrial sector. Most of Indonesia's population is very dependent on this sector because it is national food security and provides opportunities for improving welfare [2]. As a type of horticultural crop, tomatoes are plants that can grow in climate, humidity, rainfall, and any type of soil in various regions of Indonesia. Since tomato plants are known not to be difficult to cultivate, both farming in open land and closed land such as housing arrangements [3].

Coronavirus disease 2019 (Covid-19) not only causes large numbers of global deaths but also has a systematic impact on vital sectors such as finance, education, government, services, tourism, to agriculture in various countries. Until June 8, 2020, the number of people exposed to Covid-19 in the world was $6,931,000$ with positive cases reaching 131,296 and resulting in the death of 400,587 people. In comparison, at the level of East and South Asia (including Indonesia), the number of exposed was 364,196 with positive confirmed cases reaching 
13,645 and causing the deaths of 9,970 people. In other words, the region ranks 4th after the Americas, Europe, and the Eastern Mediterranean [4], [5].

The risk of being exposed to Covid-19 in the agriculture and rural sectors cannot be ignored. In its production activities, because unlike other sectors, it is done outdoors, in a relatively large area, and in low-density areas is also a threat (especially tomato farmers). However, farmers' needs from production inputs (such as water and electricity energy) are a serious concern of the government.

Farmers as the key to Indonesian food during Covid-19 are expected to remain healthy and work optimally. The problem is that at present the number of farmers in Indonesia is classified into old age (a very small number of farmers who come from millennial). This can affect food production. Lack of supply of water energy and electricity to farmers also often occurs, even during a pandemic such as this is expected to empathize with each other.

Problems regarding price fluctuations for basic commodities and food availability often occur in Indonesia, especially in remote areas that do not have the carrying capacity of agricultural land and infrastructure. This is the effect of the policies imposed by the government during Covid-19 through physical distancing to Large Scale Social Restrictions (PSBB). Interestingly, some commodities such as garlic and sugar also experienced inflation. Meanwhile, other commodities, such as tomatoes, chillies, eggs, and chicken meat, experienced a decline in their selling value. The current unfulfilled imports of several agricultural commodities are due to low national-scale production. As a result, there has been a change in policies from the exporting country to suppress production and tend to focus on domestic needs. Indirectly, this bad condition is a big threat because of the long-lasting effects of Covid19.

This can affect the production, distribution, and also food consumption. Supporting facilities for a food distribution is limited, resulting in a lack of food production. In addition, with people's changing lifestyles, the people's demand as food consumers automatically changes. This problem can cause changes in the prices of food products and harm farmers. Therefore, we need to conduct social experiments through surveys (socio-economic) of tomato farmers in Indonesia, so that it becomes an appropriate mitigation measure for planning and becomes a reference for various parties in terms of water and electricity supply.

\section{Sampling and Data}

The study was designed with a qualitative approach based on surveys. We conducted interviews with several submissions of indicators in the form of questions to informants. The question will be answered by the informant in 3 categories ( $1=$ Yes, 2 $=$ Maybe, and $3=$ No). Study locations are in 34 provinces in Indonesia with the help of informants namely tomato farmers who are members of the Farmers Group Association (Gapoktan). As for the study period, we carried out the second lockdown phase established by the Government of Indonesia in the $2^{\text {nd }}$ quartile (April 01，2020 - June 30，2020). Gapoktan tomatoes in question are those who use social media applications, such as Facebook and Instagram.

The sample size was taken using the formula [6], because population size is not yet known with certainty. If the sample size is too large, the method becomes very sensitive, making it difficult to get good goodness of fit measurements. It is recommended that a minimum sample size of 5 to 10 observations for each parameter estimated [7], [8].

The number of indicators is 2 (social and economic), with 12 questions and 6 times (this is the number of islands in Indonesia). Through calculations based on these formulas, the number of samples obtained from this study was 72 informants. The sampling technique is based on probability sampling. Probability sampling is a sampling technique that provides equal opportunities for each element (member) of the population to be selected as a sample member [9], [10], [11].

\section{Main Finding}

Table 1 explains the number of informants in this study totaling 72 samples, consisting of Gapoktan tomatoes originating from urban and rural areas throughout Indonesia. Based on the 34 provinces, informants are spread from the 6 largest islands. The sample was dominated by some Gapoktan tomatoes originating from Java and Sumatra with 7 Provinces (West Sumatra, South Sumatra, Lampung, Central Java, DI Yogyakarta, East Java, and West Nusa Tenggara), totaling 21 informants or $29.17 \%$. On the other hand, the inequality of informant units is not due to technological aspects (some of them are still traditional or farmers who do not use technology in tomato production). Meanwhile, there were 10 informants (13.89\%) in Kalimantan Island, Sulawesi Island with 13 informants (25\%), the rests were Maluku and Papua Island with 3 informants (4.17\%) each.

The duration of the standing of Gapoktan Indonesian tomatoes is quite varied. From Table 2, it can be presented that from 72 informants, the average existence of Gapoktan tomatoes is 1-5 years (36.11\%). Meanwhile, there is 1 Gapoktan or $1.39 \%$ which has been established for more than 20 years. 
Table 1. Demographics

\begin{tabular}{|c|c|c|}
\hline Provinces & Samples & Percentage $(\%)$ \\
\hline \multicolumn{3}{|c|}{ Sumatera Islands } \\
\hline Aceh & 2 & 2.78 \\
\hline North Sumatera & 2 & 2.78 \\
\hline West Sumatera & 3 & 4.17 \\
\hline Riau & 2 & 2.78 \\
\hline Jambi & 2 & 2.78 \\
\hline South Sumatera & 3 & 4.17 \\
\hline Bengkulu & 2 & 2.78 \\
\hline Lampung & 3 & 4.17 \\
\hline Bangka Belitung & 1 & 1.39 \\
\hline Riau Island & 1 & 1.39 \\
\hline \multicolumn{3}{|c|}{ Java Islands } \\
\hline DKI Jakarta & 1 & 1.39 \\
\hline West Java & 2 & 2.78 \\
\hline Central Java & 3 & 4.17 \\
\hline DI Yogyakarta & 3 & 4.17 \\
\hline East Java & 3 & 4.17 \\
\hline Banten & 2 & 2.78 \\
\hline Bali & 2 & 2.78 \\
\hline West Nusa Tenggara & 3 & 4.17 \\
\hline East Nusa Tenggara & 2 & 2.78 \\
\hline \multicolumn{3}{|c|}{ Kalimantan Islands } \\
\hline West Kalimantan & 3 & 4.17 \\
\hline Central Kalimantan & 2 & 2.78 \\
\hline South Kalimantan & 2 & 2.78 \\
\hline East Kalimantan & 3 & 4.17 \\
\hline North Kalimantan & 1 & 1.39 \\
\hline \multicolumn{3}{|c|}{ Sulawesi Islands } \\
\hline North Sulawesi & 3 & 4.17 \\
\hline Southeast Sulawesi & 2 & 2.78 \\
\hline South Sulawesi & 2 & 2.78 \\
\hline Central Sulawesi & 3 & 4.17 \\
\hline Gorontalo & 1 & 1.39 \\
\hline West Sulawesi & 2 & 2.78 \\
\hline \multicolumn{3}{|c|}{ Maluku Islands } \\
\hline Maluku & 1 & 1.39 \\
\hline North Maluku & 2 & 2.78 \\
\hline \multicolumn{3}{|c|}{ Papua Islands } \\
\hline West Papua & 2 & 2.78 \\
\hline Papua & 1 & 1.39 \\
\hline Total & 72 & 100.0 \\
\hline
\end{tabular}

Source: Survey with social media, 2020

Table 2. Profile based on long standing

\begin{tabular}{|c|c|c|}
\hline Durations & Total & Percentage (\%) \\
\hline$<1$ & 2 & 2.78 \\
\hline $1-5$ & 26 & 36.11 \\
\hline $6-10$ & 9 & 12.50 \\
\hline $11-15$ & 13 & 18.06 \\
\hline $16-20$ & 21 & 29.17 \\
\hline $20+$ & 1 & 1.39 \\
\hline & 72 & 100.0 \\
\hline
\end{tabular}

Source: Survey with social media, 2020

The existence of Gapoktan tomatoes based on 34 provinces has fulfilled the requirements as informants in the study. In addition, the institutional factor of financial support, contributions between group members, human resources, technology, and network strength also contributed to Gapoktan's existence.

Gapoktan tomato ownership status consists of 2 parties (government and private). Some of the 72 informants stated that they had been supported by the government as many as $39(54.17 \%)$ and the remaining 33 Gapoktan tomatoes came from private or private ownership ie 33 (45.83\%). Keep in mind, the legality of Gapoktan tomatoes established by the government is largely supported in terms of funding and technical aspects (training, subsidies for production machinery, fertilizer, and land) through Regionally Owned Enterprises (BUMD) and farmer cooperatives. Meanwhile, those who are under the dominant private sector are far more independent, because they are more supported by companies in their respective regions through the banking financing scheme. That is much easier so that Gapoktan tomatoes which are based on selfownership (private) is very helpful to get business credit guarantees, scale training, networking to the broad market, and ease in the distribution process (see Table 3).

Table 3. Profile based on ownership status

\begin{tabular}{|l|c|c|}
\hline \multicolumn{1}{|c|}{ Legality } & Total & Percentage (\%) \\
\hline Government & 39 & 54.17 \\
\hline Owned (private) & 33 & 45.83 \\
\hline \multirow{2}{*}{} & 72 & 100.0 \\
\hline
\end{tabular}

Source: Survey with social media, 2020

Referring to Table 4, the form of social media they use today is in accordance with market needs and is closer in terms of distribution and sales to consumers. This is much easier, because, in general information, communication, and internet networks throughout Indonesia have reached them. Generally, Gapoktan tomatoes prefer using the application in the form of FB rather than IG. As a comparison, of 72 informants, $45(62.50 \%)$ were said to have used FB and the rest were IG totaling 27 informants or $37.50 \%$.

Table 4. Profile based on social media usage

\begin{tabular}{|l|c|c|}
\hline \multicolumn{1}{|c|}{ Social media } & Total & Percentage (\%) \\
\hline Facebook & 45 & 62.50 \\
\hline Instagram & 27 & 37.50 \\
\hline \multirow{2}{*}{} & 72 & 100.0 \\
\hline
\end{tabular}

Source: Survey with social media, 2020

Interestingly what Table 5 shows, that out of 72 informants, in general, there are 21-40 members $(20.83 \%)$. Any 17 Gapoktan tomatoes or $20.83 \%$ have a membership of $61-80$ people and at least 100 members in 4 Gapoktan tomatoes. The number of 
members of each Gapoktan is based on the area of land they are working on, tomato production, and group income owned so that more members is certainly a signal of farmers' success.

Table 5. Profile based on Gapoktan members

\begin{tabular}{|c|c|c|}
\hline Member (person) & Total & Percentage (\%) \\
\hline$<20$ & 6 & 8.33 \\
\hline $21-40$ & 15 & 20.83 \\
\hline $41-60$ & 21 & 29.17 \\
\hline $61-80$ & 17 & 23.61 \\
\hline $81-100$ & 9 & 12.50 \\
\hline $100+$ & 4 & 5.56 \\
\hline & 72 & 100.0 \\
\hline
\end{tabular}

Source: Survey with social media, 2020

This type of tomato is very similar in shape to pears; it's just much smaller in shape compared to pears. With a variety of colours starting from redorange or yellow and the taste is sweet enough to make this tomato very popular. Tomatoes originate from Europe and are less well known in Indonesia (because they grow more in the region). In general, these tomatoes are eaten raw or used as a supplementary salad, but can also be used as garnishes and mixtures in drinks [12], [13].

Table 6 shows that Gapoktan generally in Indonesia is more dominant in planting and selling green tomatoes than others. From 72 informants, 30 of them tend to like green tomatoes or around $41.67 \%$. Meanwhile, farmers who planted tomatoes with plum and globe juices were still not many, namely 4 Gapoktan (5.56\%). Both tomatoes are less attractive to consumers, because of several factors including the price that tends to be expensive, the product is still rarely found in the market and has a lot of water content compared to other variances (generally Indonesian people use tomatoes for food preparations).

Table 6. Profile based on production (type of tomato)

\begin{tabular}{|l|c|c|}
\hline \multicolumn{1}{|c|}{ Varians } & Total & Percentage (\%) \\
\hline Pear tomatoes & 19 & 26.39 \\
\hline Green tomatoes & 30 & 41.67 \\
\hline Beef tomatoes & 11 & 15.28 \\
\hline Cherry tomatoes & 8 & 11.11 \\
\hline Plum tomatoes & 1 & 1.39 \\
\hline Globe tomatoes & 3 & 4.17 \\
\hline
\end{tabular}

Source: Survey with social media, 2020

For additional information, the shape of the green tomato is rather large with a green colour and a rather hard texture because it has fairly small water content. Actually these tomatoes are tomatoes that are harvested before cooking. This tomato is usually used as an ingredient of stir-fry and vegetable sauce because it tastes fresh and sour. Second, beef tomatoes have the biggest shape when compared to other types of tomatoes. Many Americans mention tomato beefsteak because the meat tends to be thick. Weight per fruit can even reach 500 grams or more. The round shape is not smooth even some are irregular. Tomato skin is thin and has a lot of seed space. Because of its very large size, this type of tomato is often used as a sandwich and burger filling. However, it is not uncommon for chefs to use it as stir-fry ingredients or other dishes that do require large tomatoes [14], [15], [16].

Third, cherry tomatoes are cute, small, and oval. When you are young the colour of the cherry tomatoes is pale green and when they are ripe they turn orange to reddish. The taste of the meat is quite sweet and contains quite a lot of water. This cherry tomato is usually used as a complement to salad or eaten fresh directly. Fourth, tomatoes with plum type, their appearance is very similar to plums. The shape is round and oval, the flesh has a lot of water content, little seed space, and has a thin skin surface. This tomato is often referred to as tomato processing of tomato paste because it is generally processed for dishes that require a relatively long time such as pasta or tomato sauce. In addition, it is generally also used for stir-frying and tomato juice [17].

The fifth is a tomato globe that has a uniform round shape with a size that is not too big. The taste was not too sour. Usually used in main meals, sandwiches, burgers, and salads. Because it is always cut or sliced when processing it, this type of tomato is often referred to as slicing tomato. This one tomato is often found in traditional markets or supermarkets and is also widely cultivated commercially [18], [19].

Problems with tomato Gapoktan in Indonesia indeed cause big problems, especially in the carrying capacity of electricity and water infrastructure in the tomato production process. The following are the results of interviews on social and economic indicators relating to these two infrastructures.

Table 7 outlines the social and economic indicators which concern the availability of electricity and water infrastructure, which have different answers by informants. For social indicators, the answer "yes" was mostly answered on the $5^{\text {th }}$ question as many as 52 people $(72.22 \%)$. Meanwhile, from a similar indicator, the dominant "maybe" the answer is stated by the informant unit in question 4 which is 35 or $48.61 \%$ Gapoktan tomatoes. From the answer "no", the highest in the third question reached 43 informants (59.72\%). Interestingly, in economic indicators, generally, Gapoktan tomatoes that give a "yes" answer are in the second question of 41 (56.94\%), while the response to the "possible" answer is in the third question, 29 informants or $40.28 \%$. On the other hand, those who answered "no" were dominant in the first question by 47 informants (65.28\%). 
Table 7. Informant response during Covid-19

\begin{tabular}{|c|c|c|c|c|c|c|c|}
\hline \multirow{3}{*}{ Indicators } & \multirow{3}{*}{ Questions } & \multicolumn{6}{|c|}{ Answers (Total) } \\
\hline & & \multicolumn{2}{|c|}{ Yes } & \multicolumn{2}{|c|}{ Maybe } & \multicolumn{2}{|c|}{ No } \\
\hline & & Total & $\%$ & Total & $\%$ & Total & $\%$ \\
\hline \multirow{6}{*}{ Social } & $\begin{array}{l}\text { Q1. Information from outside access is } \\
\text { hampered due to lack of electricity and } \\
\text { water supply? }\end{array}$ & 40 & 55.56 & 15 & 20.83 & 17 & 23.61 \\
\hline & $\begin{array}{l}\text { Q2. The management system of the } \\
\text { government does not reach farmers due to } \\
\text { electricity and water reserves? }\end{array}$ & 9 & 12.50 & 26 & 36.11 & 37 & 51.39 \\
\hline & $\begin{array}{l}\text { Q3. The lack of electricity and water } \\
\text { infrastructure affects the development of } \\
\text { farmers' knowledge? }\end{array}$ & 23 & 31.94 & 6 & 8.33 & 43 & 59.72 \\
\hline & $\begin{array}{l}\text { Q4. The technology obtained from the } \\
\text { internet and other sources has not been } \\
\text { accessed so far? }\end{array}$ & 14 & 19.44 & 35 & 48.61 & 23 & 31.94 \\
\hline & $\begin{array}{l}\text { Q5. Electricity and water supply in } \\
\text { agricultural areas that causes less social } \\
\text { conflict between farmers? }\end{array}$ & 52 & 72.22 & 4 & 5.56 & 16 & 22.22 \\
\hline & $\begin{array}{l}\text { Q6. Demand and fuel prices have jumped } \\
\text { sharply due to electricity and water } \\
\text { depreciation affecting speculators? }\end{array}$ & 38 & 52.78 & 10 & 13.89 & 24 & 33.33 \\
\hline \multirow{6}{*}{ Economic } & $\begin{array}{l}\text { Q7. Production expenses adjust the } \\
\text { availability of electricity and water? }\end{array}$ & 25 & 34.72 & 0 & 0.00 & 47 & 65.28 \\
\hline & $\begin{array}{l}\text { Q8. Is the income from the sale of } \\
\text { tomatoes very dependent on electricity and } \\
\text { water infrastructure? }\end{array}$ & 41 & 56.94 & 5 & 6.94 & 26 & 36.11 \\
\hline & $\begin{array}{l}\text { Q9. The carrying capacity of electricity } \\
\text { and water has an effect on the } \\
\text { effectiveness of tomato production? }\end{array}$ & 17 & 23.61 & 29 & 40.28 & 26 & 36.11 \\
\hline & $\begin{array}{l}\text { Q10. Planting efficiency relies heavily on } \\
\text { electricity and water supply? }\end{array}$ & 33 & 45.83 & 1 & 1.39 & 38 & 52.78 \\
\hline & $\begin{array}{l}\text { Q11. Has the harvest distribution process } \\
\text { been disrupted due to minimal electricity } \\
\text { and water infrastructure? }\end{array}$ & 19 & 26.39 & 8 & 11.11 & 45 & 62.50 \\
\hline & $\begin{array}{l}\text { Q12. The level of market demand for } \\
\text { tomatoes is less relevant to the support of } \\
\text { electricity and water infrastructure? }\end{array}$ & 26 & 36.11 & 13 & 18.06 & 33 & 45.83 \\
\hline
\end{tabular}

Source: Survey with social media, 2020

Table 8. Result of descriptive statistic

\begin{tabular}{|c|c|c|c|c|}
\hline Indicators & $\begin{array}{c}\text { No. of } \\
\text { questions }\end{array}$ & Answers & Mean & $\begin{array}{l}\text { Std. } \\
\text { dev. }\end{array}$ \\
\hline \multirow{3}{*}{ Social } & \multirow{3}{*}{6} & Yes & 29.33 & 16.68 \\
\hline & & Maybe & 16.00 & 12.18 \\
\hline & & No & 26.67 & 10.97 \\
\hline \multicolumn{3}{|c|}{ Total } & 72.00 & \\
\hline \multirow{3}{*}{ Economic } & \multirow{3}{*}{6} & Yes & 26.83 & 8.95 \\
\hline & & Maybe & 9.33 & 10.75 \\
\hline & & No & 35.83 & 9.11 \\
\hline \multicolumn{3}{|c|}{ Total } & 72.00 & \\
\hline
\end{tabular}

Source: Survey with social media, 2020

As a comparison, the majority of informants in social indicators said "yes" with an average of 29.33. This number is slightly below those who answered "no" by 26.67 and the answer "no" was 16.00. From the economic indicators, Table 8 summarizes the fundamental differences, this time the majority of informants stated that "no" reached an average of 35.83. For those who answered "yes", an average of 35.83 , and of the total number (72), only a small proportion stated "no" ie 9.33. With 12 items of questions, they are generally varied and this indicates that Gapoktan tomatoes in Indonesia have different characters and understandings.

\section{Discussion}

There are several supporting factors in the development of the agricultural sector, including development education, production credit, joint activities by farmers, improvement, and expansion of agricultural land, and national planning of agricultural development. Specifically, the availability of infrastructures such as electricity and water networks is very fundamental for their work [20].

The important role of infrastructure to promote a higher level of the economy affects the availability of quality infrastructure itself. The government needs to 
realize physical spending for investment such as research and development on agriculture and irrigation, rural education and infrastructure, including roads, electricity, and water supply [21], [22], [23], [24], [25], [26].

Development in the field of agriculture, aims to increase awareness, willingness, and ability to live healthy for everyone so that the highest degree of community food fulfillment can be achieved, as an investment for the development of socially and economically productive human resources [27], [28].

The impact of public capital or infrastructure varies by country, region, and sector depending on the quantity and quality of infrastructure development itself. The better the condition of infrastructure, the better is the level of mobility. Accuracy in the provision of infrastructure (especially electricity and water) in this case can play an important role in the economic growth and development of a region. Areas with limited access experience significantly higher prices and scarce supply of resources compared to areas with better access. Government expenditure used to finance the construction of public facilities such as electricity networks will directly affect the welfare of the community, especially farmers [29].

Economic conditions are an important factor and assessment of whether to re-elect incumbent or not. From this point of view, leaders from each country are political leaders who try to be re-elected in the next general election, it would be more profitable to build infrastructure that is considered to have a major influence on the economy, especially on water supply [30], [31].

\section{Conclusion}

Referring to the results of the analysis that has been presented previously, we found a variety of answers raised by the informants. From 72 samples, this study can conclude that in general Gapoktan tomatoes assume there are social problems. From economic indicators, their dominant states that there were no serious problems related to the supply of electricity and water infrastructure during Covid-19. The answers consisting of 12 questions are indeed quite varied, so we draw conclusions based on social experimentation.

From the proportion of electricity infrastructure usage, it can be concluded that electrical energy has contributed to the efforts of tomato farmers. That is because the electricity supply is widely used for economic activities in economic business actors (such as agriculture). Electricity infrastructure affects the agricultural sector both directly and indirectly through its role as an input factor in the production of Gapoktan tomatoes. When access to energy such as electricity in villages from industrial operations is difficult, the process of producing goods and services will also be hampered.
Infrastructure refers to the physical system that provides public facilities needed to meet basic human needs in the social and economic sphere, in this case, irrigation (clean water). The infrastructure system will be the availability of water, is the main supporter of the functions of social and economic systems in people's daily lives. Infrastructure systems can be defined as basic facilities or structures, equipment, installations that are built, and needed for the functioning of the Gapoktan tomato social system and economic system in Indonesia.

The Government of Indonesia and supporting parties need to increase production capacity and increase the pipeline, supervision, and arrangement of water users and electricity networks for priority scale in the agricultural sector.

This study has several limitations from observations (the sampling period and sample data) which are considered limited. Because the informant unit does not represent all remote areas (such as districts and cities), researchers in the future will add more samples or expand survey time.

\section{References}

[1]. Statistik, B. P. (2020). Statistical Yearbook of Indonesia 2020. Jakarta: Badan Pusat Statistik.

[2]. Surya, D., Siti, M., Dirga, L., \& Caisar, D. D. (2020). An Agroforestry Consortium: A Multiderminant in Instituting an Agrisilviculture System to Improve Welfare. Virtual Economics, 3(1), 95-111.

[3]. Darma, S., Kustiawan, W., \& Sumaryono, S. (2017). Evaluation of Land Damage Status for Biomassa Production in Loakulu Subdistrict Kutai Kartanegara Regency of East Kalimantan Province, Indonesia. International Journal of Scientific \& Technology Research, 6(7), 106-110.

[4]. Biswas, B., Roy, S. K., \& Roy, F. (2020). Students Perception of Mobile Learning during COVID-19 in Bangladesh: University Student Perspective. Aquademia, 4(2), ep20023.

[5]. Toquero, C. M. D. (2020). Will COVID-19 Bring the Armageddon? Expanding Psychosocial Support and Environmental Care: An Autoethnographic Research. Aquademia, 4(2), ep20022.

[6]. Hair, Jr., Joseph, F., Black, W. C., Babin, B. J., \& Anderson, R. E. (2010). Multivariate Data Analysis, $7^{\text {th }}$ Edition. Prentice Hall International, New York.

[7]. Schermelleh-Engel, K., Moosbrugger, H., \& Müller, H. (2003). Evaluating the fit of structural equation models: Tests of significance and descriptive goodness-of-fit measures. Methods of psychological research online, 8(2), 23-74.

[8]. Palinkas, L. A., Horwitz, S. M., Green, C. A., Wisdom, J. P., Duan, N., \& Hoagwood, K. (2015). Purposeful sampling for qualitative data collection and analysis in mixed method implementation research. Administration and policy in mental health and mental health services research, 42(5), 533-544. 
[9]. Elfil, M., \& Negida, A. (2017). Sampling methods in clinical research; an educational review. Emergency, 5(1).

[10]. Schreuder, H. T., Gregoire, T. G., \& Weyer, J. P. (2001). For what applications can probability and non-probability sampling be used?. Environmental Monitoring and Assessment, 66(3), 281-291.

[11]. Taherdoost, H. (2016). Sampling Methods in Research Methodology; How to Choose a Sampling Technique for Research. International Journal of Academic Research in Management, 5(2), 18-27.

[12]. Bergougnoux, V. (2014). The history of tomato: from domestication to biopharming. Biotechnology advances, 32(1), 170-189.

[13]. Mehta, R. (2017). History of Tomato (Poor Man's Apple). IOSR Journal Of Humanities and Social Science, 22(8), 31-34.

[14]. Heflebower, R., \& Washburn, C. (2010). The influence of different tomato varieties on acidity as it relates to home canning. Journal of Extension, 48(6), 5.

[15]. Kurze, E., Lo Scalzo, R., Campanelli, G., \& Schwab, W. (2018). Effect of tomato variety, cultivation, climate and processing on Sola 14, an allergen from Solanum lycopersicum. Plos one, 13(6), e0197971.

[16]. Tigist, A., Workneh, T. S., \& Woldetsadik, K. (2012). Effects of variety on yield, physical properties and storability of tomato under ambient conditions. African Journal of Agricultural Research, 7(45), 6005-6015.

[17]. Ávila-Juárez, L., \& Miranda-Rodríguez, H. (2018). Variations in bioactive content in different tomato trusses due to elicitor effects. Journal of Chemistry, 2018.

[18]. Chime, A. O., Aiwansoba, R. O., Osawaru, M. E., \& Ogwu, M. C. (2017). Morphological evaluation of tomato (Solanum lycopersicum Linn.) cultivars. Makara Journal of Science, 21(2), 97-106.

[19]. Olaniyi, J. O., Akanbi, W. B., Adejumo, T. A., \& Ak, O. G. (2010). Growth, fruit yield and nutritional quality of tomato varieties. African Journal of Food Science, 4(6), 398-402.

[20]. Sarmin, S., Widiyono, I., \& Widiyanto, S. (2016). Pembangunan Infrastruktur Pertanian dan Sosial Dalam Rangka Mempersiapkan Selopamioro Mandiri Sejahtera Berbasis Potensi Lokal. Jurnal Pengabdian kepada Masyarakat (Indonesian Journal of Community Engagement), 2(1), 30-38.
[21]. Fan, S., Hazell, P., \& Thorat, S. (2000). Government spending, growth and poverty in rural India. American Jjournal of Agricultural Economics, 82(4), 1038-1051.

[22]. Canning, D. (1999). Infrastructure's Contribution to Aggregate Output. World Bank Policy Research Working Paper, (2246).

[23]. Herranz-Loncán, A. (2007). Infrastructure investment and Spanish economic growth, 1850 1935. Explorations in Economic History, 44(3), 452468.

[24]. Fedderke, J. W., \& Bogetić, Ž. (2009). Infrastructure and Growth in South Africa: Direct and Indirect Productivity Impact of 19 Infrastructure Measures. World Development, 37(9), 1522-1539.

[25]. Beyzatlar, M. A., \& Kustepeli, Y. R. (2011). Infrastructure, economic growth and population density in Turkey. International Journal of Economic Sciences and Applied Research, 4(3), 3957.

[26]. Shi, Y., Guo, S., \& Sun, P. (2017). The role of infrastructure in China's regional economic growth. Journal of Asian Economics, 49, 26-41.

[27]. Bakare, A. A., \& Olubokun, S. (2011). Health care expenditure and economic growth in Nigeria: An empirical study. Journal of Emerging Trends in Economics and Management Sciences, 2(2), 83-87.

[28]. Bedir, S. (2016). Healthcare expenditure and economic growth in developing countries. Advances in Economics and Business, 4(2), 76-86.

[29]. Fullerton Jr, M. T., Morales, C. R., \& Walke, A. G. (2014). The effects of education, infrastructure, and demographics on regional income performance in Missouri. Regional and Sectorial Economic Studies, 14(1), 5-22.

[30]. Hulten, C. R., \& Schwab, R. M. (1993). Infrastructure spending: where do we go from here?. National Tax Journal, 46(3), 261-273.

[31]. Démurger, S. (2001). Infrastructure development and economic growth: an explanation for regional disparities in China?. Journal of Comparative economics, 29(1), 95-117. 